University of Nebraska - Lincoln

DigitalCommons@University of Nebraska - Lincoln

Mammalogy Papers: University of Nebraska

State Museum

Museum, University of Nebraska State

April 1967

\title{
Second Record of Myotis volans from North Dakota
}

Hugh H. Genoways

University of Kansas, Lawrence, h.h.genoways@gmail.com

Follow this and additional works at: https://digitalcommons.unl.edu/museummammalogy

Part of the Zoology Commons

Genoways, Hugh H., "Second Record of Myotis volans from North Dakota" (1967). Mammalogy Papers: University of Nebraska State Museum. 60.

https://digitalcommons.unl.edu/museummammalogy/60

This Article is brought to you for free and open access by the Museum, University of Nebraska State at DigitalCommons@University of Nebraska - Lincoln. It has been accepted for inclusion in Mammalogy Papers: University of Nebraska State Museum by an authorized administrator of DigitalCommons@University of Nebraska Lincoln. 


\section{Short Notes}

\section{Second Record of Myotis volans from North Dakota HUGH H. GENOWAYS}

The first record of the long-legged myotis, Myotis volans interior, in North Dakota was reported by Jones and Genoways (Trans. Kansas Acad. Sci., 69:89, 1966) on the basis of a single male from $1 \mathrm{mi}$. S and $1 \mathrm{mi}$. W Medora, Billings County. On 25 May 1966, nine adult females (KU 106932-40) of this bat were obtained by Donald R. Johnson in Granville, McHenry County. These specimens extend the known geographic distribution of $M$. $v$. interior approximately 160 miles to the northeast from the previously reported North Dakotan locality and represent the northeasternmost locality of record for the species in North America.

The bats were captured in a mist net stretched along the eaves of a house. Johnson estimated that the attic of the house contained a colony of approximately 40 individuals. Because only females were netted, it is presumed that they represented an incipient maternity colony, but none of the specimens yet evidenced gross reproductive activity. Mean and extremes of length of forearm for the nine specimens, all preserved in spirits, are $37.9(36.3-39.4) \mathrm{mm}$.

-Museum of Natural History, The University of Kansas, Lawrence.

Transactions of the Kansas Academy of Science, Vol. 69, Nos. 3-4, 1966. Published April 25, 1967. 